\title{
FAKTOR-FAKTOR YANG MEMPEGARUHI IBU DALAM PEMBERIAN ASI EKSKLUSIF PADA BAYI 6-12 BULAN DI RW O5 DESA KARANGJATI WILAYAH KERJA PUSKESMAS BERGAS KABUPATEN SEMARANG
}

\author{
Dini Mega Sari \\ Program Studi D IV Kebidanan STIKes Ngudi Waluyo
}

\begin{abstract}
ABSTRAK
ASI eksklusif adalah pemberian ASI saja tanpa memberikan makanan atau minuman lain sampai bayi berusia 6 bulan. Namun kenyataannya, pemberian ASI secara eksklusif baik di Indonesia maupun di Kabupaten Semarang masih rendah. Hal ini ada banyak faktor yang mempengaruhi, diantaranya: pengetahuan, pendidikan, pekerjaan, sikap ibu, dan faktor eksternal yaitu promosi susu formula, dukungan, sosial budaya, sumber informasi dan penolong persalinan. Tujuan dari penelitian ini adalah untuk mengetahui faktor-faktor yang mempengaruhi ibu menyusui terhadap pemberian ASI eksklusif pada bayi 6-12 bulan di Desa Karangjati Wilayah kerja Puskesmas Bergas Kabupaten Semarang.

Jenis penelitian ini adalah penelitian deskriptif korelasi dengan pendekatan cross sectional. Populasinya adalah seluruh ibu yang memiliki anak usia 6-12 bulan di Desa Karangjati dengan jumlah 76 orang. Pengambilan sampel menggunakan teknik total sampel, sehingga jumlah sampel yang digunakan adalah sama dengan jumlah populasi, yaitu 76 orang.

Hasil penelitian menunjukkan bahwa tidak ada hubungan secara bermakna antara pendidikan dengan pemberian ASI eksklusif dengan p-value 0,720 > $\alpha(0,05)$, ada hubungan secara bermakna antara pekerjaan dengan pemberian ASI eksklusif dengan p-value $0,007<\alpha$ $(0,05)$, dan ada hubungan secara bermakna antara pengetahuan dengan pemberian ASI eksklusif dengan p-value $0,020<\alpha(0,05)$.
\end{abstract}

Kata Kunci : ASI Eksklusif, Pengetahuan, Umur, Pekerjaan 


\begin{abstract}
Giving breast milk is very important for optimal growth and development of babies both physically and mentally.. It gives breast milk to babies until 0-6 months old without giving other food or beverage. But in reality, giving exclusive breast milk both in Indonesia and in Semarang regency is still low. There are many factors influencing it they are: knowledge, education, job, mother's attitude, disease and external factors for example formula milk promotion, support, social culture, information source and labour helper. The objective of this research was to identify the factors influencing breastfeeding mother to give exclusive breast milk for babies 6-12 months at Karangjati Village of the area is Bergas health center, Semarang Regency.

This research type was correlation descriptive research with cross sectional approach. Its population was all mothers having 6-12 months old babies at Karangjati Village as many as 76 people. Sample taking used total sampling technique, so that the used samples were equal to the number of population, as many as 76 .

The results of this research indicated that there was no significant relationship between education and giving exclusive breast milk with p-value $0.720>\alpha(0.05)$, there was a significant relationship between job and giving exclusive breast milk with p-value $0.007<\alpha$ (0.05), and there was a significant relationship between knowledge and giving exclusive breast milk with p-value $0.020<\alpha(0.05)$.
\end{abstract}

Keywords : Exclusive breast milk, Knowledge, Age, Job 


\section{PENDAHULUAN}

Air Susu Ibu (ASI) adalah suatu emulsi lemak dalam larutan protein, laktosa, dan garam-garam anorganik yang sekresi oleh kelenjar mamae ibu, yang berguna sebagai makanan bagi bayinya. ASI dalam jumlah cukup merupakan makanan terbaik pada bayi dan dapat memenuhi kebutuhan gizi bayi selama 6 bulan pertama (Depkes, 2008).

Menurut World Health Organization (WHO) Tahun 2002 dalam Depkes (2005), pemenuhan kebutuhan gizi bayi 0-6 bulan mutlak diperoleh melalui ASI bagi bayi dengan ASI eksklusif. Berdasarkan hal ini maka upaya perbaikan gizi bayi 0-6 bulan dilakukan melalui perbaikan gizi ibu sebelum dan pada masa pemberian ASI eksklusif. Selain itu Bank Dunia (World Bank) Tahun 2006 mengemukakan bahwa upaya perbaikan gizi bayi 0-6 bulan didasarkan bahwa gizi kurang pada anak usia kurang dari 2 tahun akan berdampak terhadap penurunan pertumbuhan fisik, perkembangan otak, kecerdasan, dan produktivitas, dan dampak ini sebagian besar tidak dapat diperbaiki.

Menyikapi permasalahan pentingnya pemberian ASI bagi bayi, pemerintah Indonesia telah menggalakkan program pemberian ASI Esklusif sejak tahun 1990 yang dikenal dengan Gerakan Nasional Peningkatan Air Susu Ibu (PP-ASI). Sehubungan dengan itu telah ditetapkan dengan Keputusan Menteri Kesehatan No.450/MENKES/IV/2004 tentang Pemberian ASI secara eksklusif pada bayi Indonesia (Depkes RI, 2005).

Berdasarkan data cakupan pemberian ASI Eksklusif secara global dari WHO pada bulan Februari 2014secara umum kurang dari $40 \%$ bayi di bawah 6 bulan diberikan ASI Eksklusif. Konseling dan dukungan yang adekuat yang perlu diberikan kepada ibu untuk memulai dan mempertahankan praktik pemberian ASI Eksklusif.
Menurut data dari Dinas Kesehatan Kabupaten Semarang tahun 2013 bahwa cakupan ASI Eksklusif di wilayah Kabupaten Semarang untuk bayi usia 1-3 bulan hanya sebesar 52\%, yang berusia 3-6 bulan hanya $42 \%$. Hal ini menunjukkan bahwa pemberian ASI Eksklusif di Kabupaten Semarang masih rendah. Banyak alasan yang menjadi faktor penyebab kenapa ibu tidak memberikan ASI Eksklusif kepada bayinya. Faktor internal yaitu pengetahuan, pendidikan, pekerjaan, sikap ibu, penyakit dan faktor eksternal yaitu promosi susu formula, dukungan, sosial budaya, sumber informasi danpenolong persalinan (Dinkes, 2013).

\section{METODE PENELITIAN}

Jenis penelitian yang digunakan dalam penelitian ini adalah penelitian yang bersifat deskriptif korelasi dengan pendekatan cross sectional. Menurut Nursalam (2008), penelitan deskriptif korelasi adalah penelitian/ penelaahan hubungan antara dua variabel pada suatu situasi atau sekelompok subjek. Pendekatan yang digunakan dalam penelitian ini adalah "Cross Sectional" yaitu suatu penelitian dimana antara variabel bebas dan terikat, yaitu faktor-faktor yang mempengaruhi ibu dalam pemberian ASI Eksklusif. Dengan menggunakan pendekatan cross sectional dimana data yang menyangkut variabel bebas dan variabel terikat, yang akan diamati dalam waktu bersamaan (Notoatmodjo, 2005).

\section{HASIL PENELITIAN}

Tabel 1 Distribusi Frekuensi Berdasarakan Ibu yang Memiliki Bayi 6-12 Bulan di RW 05 Desa Karangjati Wilayah kerja Puskesmas Bergas Kabupaten Semarang

\begin{tabular}{lcc}
\hline Umur & Frekuensi & $\begin{array}{c}\text { Persentase } \\
(\boldsymbol{\%})\end{array}$ \\
\hline$<20$ Tahun & 10 & 13,1 \\
20-35 Tahun & 55 & 72,4 \\
$>$ 35 Tahun & 11 & 14,5 \\
\hline Jumlah & 76 & 100,0 \\
\hline
\end{tabular}


Tabel 2 Distribusi Frekuensi Berdasarkan Pendidikan Ibu yang Memiliki Bayi 6-12 Bulan di RW 05 Desa Karangjati Wilayah Kerja Puskesmas Bergas Kabupaten Semarang

\begin{tabular}{lcc}
\hline Pendidikan Ibu & Frek. & $\begin{array}{c}\text { Persentase } \\
(\%)\end{array}$ \\
\hline Dasar (SD/SMP) & 33 & 43,4 \\
Menengah (SMA) & 35 & 46,1 \\
Tinggi (Perguruan & 8 & 10,5 \\
Tinggi) & & \\
\hline Jumlah & 76 & 100,0 \\
\hline
\end{tabular}

Tabel 3 Distribusi Frekuensi Berdasarkan Pekerjaan Ibu yang Memiliki Bayi 6-12 Bulan di RW 05 Desa Karangjati Wilayah Kerja Puskesmas Bergas Kabupaten Semarang

Pekerjaan Ibu Frekuensi Persentase
(\%)

\begin{tabular}{lcc}
\hline Bekerja & 44 & 57,9 \\
Tidak Bekerja & 32 & 42,1 \\
\hline Jumlah & 76 & 100,0 \\
\hline
\end{tabular}

Tabel 4 Distribusi Frekuensi Berdasarkan Pengetahuan Ibu yang Memiliki Bayi 6-12 Bulan tentang ASI Eksklusif di RW 05 Desa Karangjati Wilayah Kerja Puskesmas Bergas Kabupaten Semarang

\begin{tabular}{lll}
\hline $\begin{array}{c}\text { Pengetahuan } \\
\text { Ibu }\end{array}$ & Frekuensi & $\begin{array}{c}\text { Persentase } \\
(\mathbf{\%})\end{array}$ \\
\hline Kurang & 29 & 38,2 \\
Cukup & 20 & 26,3 \\
Baik & 27 & 35,5 \\
\hline Jumlah & 76 & 100,0 \\
\hline
\end{tabular}

Tabel 5 Distribusi Frekuensi Berdasarkan Pemberian ASI Eksklusif pada Ibu yang Memiliki Bayi 6-12 Bulan di RW 05 Desa Karangjati Wilayah Kerja Puskesmas Bergas Kabupaten Semarang

\begin{tabular}{lcc}
\hline $\begin{array}{l}\text { Pemberian } \\
\text { ASI }\end{array}$ & Frekuensi & $\begin{array}{c}\text { Persentase } \\
(\%)\end{array}$ \\
Eksklusif & & \\
\hline Tidak ASI & 52 & 68,4 \\
Eksklusif & 24 & 31,6 \\
ASI & & \\
Eksklusif & & \\
\hline Jumlah & 76 & 100,0 \\
\hline
\end{tabular}

Pada hasil penelitian ini ibu dengan pendidikan dasar (SD/SMP) yang memberikan ASI eksklusif sejumlah $36,4 \%$, sedangkan ibu dengan pendidikan menengah (SMA/sederajat) yang memberikan ASI eksklusif sejumlah 28,6\% dan ibu dengan pendidikan tinggi (perguruan tinggi) yang memberikan ASI eksklusif sejumlah 25,0\%. Berdasarkan uji Chi Square diperoleh nilai $\chi^{2}$ hitung 0,656 dengan $\mathrm{p}$-value 0,720 . Oleh karena $\mathrm{p}$-value $0,720>\alpha(0,05)$, maka disimpulkan bahwa tidak ada hubungan secara bermakna antara pendidikan denganpemberian ASI eksklusif pada ibu yang memiliki bayi usia 6-12 bulan di RW 05 Desa Karangjati Wilayah Kerja Puskesmas Bergas Kabupaten Semarang.

Ibu yang bekerja yang memberikan ASI eksklusif sejumlah $18,2 \%$, sedangkan ibu yang tidak bekerja yang memberikan ASI eksklusif sejumlah 50,0\%.

Berdasarkan uji Chi Square diperoleh nilai $\chi^{2}$ hitung 7,270 dengan nilai p-value 0,007. Oleh karena p-value $0,007<\alpha(0,05)$, maka disimpulkan bahwa ada hubungan secara bermakna antara pekerjaan dengan pemberian ASI eksklusif pada ibu yang memiliki bayi usia 6-12 bulan di RW 05 Desa Karangjati Wilayah kerja Puskesmas Bergas Kabupaten Semarang. 
Ibu dengan pengetahuan kurang yang memberikan ASI eksklusif sejumlah 20,7\%, sedangkan ibu dengan pengetahuan cukup yang memberikan ASI eksklusif sejumlah 20,0\%, dan ibu dengan pengetahuan baik yang memberikan ASI eksklusif sejumlah $51,9 \%$.

Berdasarkan uji Chi Square diperoleh nilai $\chi^{2}$ hitung 7,817 dengan nilai $p$-value 0,020 . Oleh karena p-value $0,020<\alpha$ $(0,05)$, maka disimpulkan bahwa ada hubungan secara bermakna antara pengetahuan dengan pemberian ASI eksklusif pada ibu yang memiliki bayi usia 6-12 bulan di RW 05 Desa Karangjati Wilayah Kerja Puskesmas Bergas Kabupaten Semarang

\section{PEMBAHASAN}

Berdasarkan hasil penelitian sebagaimana disajikan tabel 4.2 diketahui bahwa dari 76 responden ibu yang memiliki bayi 6-12 bulan di RW 05 Desa Karangjati Wilayah Kerja Puskesmas Bergas Kabupaten Semarang, ibu memiliki pendidikan dasar (SD/SMP) sejumlah 33 orang $(43,4 \%)$ yang memiliki pendidikan menengah (SMA) sejumlah 35 orang $(46,1 \%)$, dan yang memiliki pendidikan tinggi sejumlah 8 orang $(10,5 \%)$. Ini menunjukkan bahwa sebagian besar ibu yang memiliki bayi 6-12 bulan di RW 05 Desa Karangjati Wilayah Kerja Puskesmas Bergas Kabupaten Semarang berpendidikan menengah (SMA sederajat).

$$
\text { Kebanyakan ibu memiliki }
$$

pendidikan menengah (SMA sederajat) disebabkan saat ini pemerintah telah mencanangkan wajib belajar 12 tahun, atau sampai tingkat SMA. Oleh karena itu, dari program pemerintah bahwa diharapkan bagi masyarakat Indonesia setidaknya mengenyam pendidikan sampai 12 tahun atau setidaknya sampai tingkat SMA. Jadi, sudah wajar jika masyarakat terutama para ibu yang memiliki bayi 6-12 bulan di RW 05 Desa Karangjati Wilayah Kerja Puskesmas Bergas Kabupaten Semarang lebih banyak yang memiliki pendidikan menengah atau setingkat SMA.

Pendidikan dapat mempengaruhi seseorang termasuk juga perilaku akan pola hidup terutama dalam memotivasi untuk sikap berperan serta dalam pembangunan kesehatan (Nursalam \& Siti Pariani, 2009).

Menurut Kuncoroningrat (1997) yang dikutip oleh Nursalam dan Siti Pariani (2009), makin tinggi tingkat pendidikan seseorang, makin mudah menerima informasi sehingga makin banyak pula pengetahuan yang dimiliki. Sebaliknya pendidikan yang kurang akan menghambat perkembangan seseorang terhadap nilainilai yang baru diperkenalkan.

Berdasarkan hasil penelitian sebagaimana disajikan pada tabel 4.3 diketahui bahwa dari 76 responden ibu yang memiliki bayi 6-12 bulan di RW 05 Desa Karangjati Wilayah Kerja Puskesmas Bergas Kabupaten Semarang, lebih banyak ibu yang bekerja sejumlah 44 orang $(57,9 \%)$ dan yang tidak bekerja sejumlah 32 orang $(42,1 \%)$. Ini menunjukkan bahwa ibu yang memiliki bayi 6-12 bulan di Desa Karangjati Wilayah kerja Puskesmas Bergas Kabupaten Semarang lebih banyak didominasi oleh ibu yang bekerja.

Para ibu yang memiliki bayi 6-12 bulan di RW 05 Desa Karangjati Wilayah Kerja Puskesmas Bergas Kabupaten Semarang lebih banyak yang bekerja ini disebabkan di daerah sekitar Desa Karangjati ini banyak sekali berdiri pabrikpabrik industri yang lebih banyak mempekerjakan penduduk setempat sebagai tenaga kerja, terutama adalah para wanita. Hal ini bisa dilihat bahwa banyak para buruh pabrik industri seperti PT. Apac Inti Corpora, PT. Coca Cola, dan PT. Star Light di Kabupaten Semarang ini lebih banyak wanita dibandingkan laki-laki. Sehingga banyak para ibu di wilayah Kabupaten Semarang yang memiliki pekerjaan dan pekerjaan yang paling banyak adalah sebagai buruh pabrik.

Banyak ibu yang bekerja juga bisa disebabkan kebanyakan penghasilan suami memang dirasa oleh ibu masih kurang dapat 
mencukupi semua kebutuhan rumah tangga. Oleh karena itu, banyak bagi para ibu yang memilih untuk bekerja agar dapat mendukung ekonomi keluarga, membantu mencari nafkah suami, dan akhirnya dapat memenuhi segala kebutuhan rumah tangganya.

Banyak perempuan mendapat kesempatan yang semakin besar untuk memperoleh pendidikan tinggi sebagaimana halnya kaum laki-laki. Kesempatan untuk bekerja semakin terbuka untuk perempuan. Alasan yang mendasar bagi seorang perempuan untuk bekerja tidak selalu sama antara yang satu dengan yang lainnya. Alasan yang umum dijumpai ialah karena kebutuhan keuangan, untuk memperkaya pengalaman dan pengetahuan pribadi, menghindari tugas rumah tangga, ketidakpuasan hidup dan hasrat untuk berprestasi (Hogg, 2006).

Kaitannya dengan pemberian ASI eksklusif, status pekerjaan ibu dapat mempengaruhi pemberian ASI Eksklusif. Hal ini sebagaimana diungkapkan Depkes (2010) bahwa tekanan ekonomi menyebabkan banyak ibu-ibu yang bekerja di luar rumah, sehingga pemberian ASI eksklusif sering diabaikan, meskipun sebenarnya bekerja bukanlah alasan untuk tidak memberikan ASI eksklusif karena waktu ibu bekerja bayi dapat diberi ASI perah yang diperoleh sebelumnya dari ASI itu sendiri (Depkes, 2010).

Berdasarkan hasil penelitian sebagaimana disajikan pada tabel 4.4 diketahui bahwa pengetahuan ibu tentang ASI eksklusif di RW 05 Desa Karangjati Wilayah Kerja Puskesmas Bergas Kabupaten Semarang dalam kategori kurang sejumlah 29 orang $(38,2 \%)$ dalam kategori cukup sejumlah 20 orang $(26,3 \%)$ dan dalam kategori baik sejumlah 27 orang $(35,5 \%)$. Hal ini dapat dilihat dari kuesioner yang diisi oleh responden yaitu ibu yang mengetahui pengertian dari pemberian ASI Eksklusif (54\%), ibu yang mengetahui manfaat dari pemberian ASI Eksklusif (45\%), ibu yang mengetahui beberapa kendala dalam pemberian ASI Eksklusif
(47\%), ibu yang mengetahui bagaimana cara agar berhasil dalam pemberian ASI Eksklusif (38\%), ibu yang mengetahui bagaimana kualitas ASI yang baik (51\%), ibu yang mengetahui bagaimana cara menyusui yang tepat (57\%), ibu yanag menegetahui bagaimana cara menyimpan ASI (36\%). Hal tersebut menunjukkan bahwa pengetahuan ibu tentang ASI eksklusif di RW 05 Desa Karangjati Wilayah Kerja Puskesmas Bergas Kabupaten Semarang lebih banyak dalam kategori kurang.

Kurangnya pengetahuan tentang ASI eksklusif ini bisa disebabkan banyak para ibu di RW 05 Desa Karangjati Wilayah Kerja Puskesmas Bergas Kabupaten Semarang yang enggan mencari informasi tentang ASI eksklusif.

Pengetahuan adalah hasl pengindraan manusia, atau hasil tahu seseorang terhadap objek melalui indra yang dimilikinya (mata, hidung, telinga, dan sebagainya). Dengan sendirinya ada waktu pengindraan sehingga menghasilkan pengetahuan tersebut sangat dipengaruhi oleh intensitas perhatian terhadap objek. Sebagian besar pengetahuan seseorang diperoleh memalui indra pendengaran (telinga) dan indra pendengaran (mata) (Notoadmodjo, 2010).

Namun, informasi secara detil tentang ASI eksklusif jarang sekali didapatkan oleh ibu. Hal ini biasanya dikarenakan faktor pekerjaan ibu yang telah menyita banyak waktu ibu setiap harinya, belum lagi pekerjaan rumah yang menumpuk yang harus diselesaikan oleh ibu. Hal ini mengakibatkan pencarian informasi tentang ASI eksklusif menjadi terabaikan.

Kurangnya pengetahuan ibu tentang ASI eksklusif juga bisa dipengaruhi oleh pendidikan ibu. Berdasarkan hasil isian kuesioner, didapatkan hampir sebagian ibu yang hanya memiliki pendidikan dasar (SD atau SMP) sejumlah 33 orang $(43,4 \%)$. Pendidikan seseorang akan berpengaruh terhadap daya serapnya terhadap informasiinformasi yang datang dari luar, dimana orang dengan pendidikan tinggi akan lebih mudah dalam hal memahami informasi 
yang datang dari luar. Sebaliknya, orang dengan pendidikan rendah akan mengalami kesulitan untuk menyerap informasi dari luar termasuk informasi tentang ASI eksklusif.

Hal yang sama juga dinyatakan oleh Prasetyono (2009) bahwa Tingkat pendidikan seseorang akan berpengaruh dalam memberikan respon terhadap sesuatu yang datang dari luar. Orang yang berpendidikan tinggi akan memberikan respon yang lebih rasional terhadap informasi yang datang dan alasan berfikir sejauh mana keuntungan yang mungkin akan mereka peroleh dari gagasan tersebut.

Bagi sebagian ibu, menyusui merupakan tindakan yang alamiah dan naluriah. Oleh karena itu, mereka beranggapan bahwa menyusui tidak perlu dipelajari. Namun, kebanyakan ibu kurang menyadari pentingnya ASI sebagai makanan utama bayi. Mereka hanya mengetahui ASI adalah makanan yang diperlukan bayi tanpa memperhatikan aspek lainnya.

Berdasarkan hasil penelitian sebagaimana disajikan tabel 4.5 diketahui bahwa ibu yang memiliki bayi 6-12 bulan di RW 05 Desa Karangjati Wilayah Kerja Puskesmas Bergas Kabupaten Semarang, yang memberikan ASI eksklusif sejumlah 24 orang $(68,4 \%)$, dan yang tidak memberikan ASI eksklusif sejumlah 52 orang $(31,6 \%)$. Ini menunjukkan bahwa ibu yang memiliki bayi 6-12 bulan di RW 05 Desa Karangjati Wilayah Kerja Puskesmas Bergas Kabupaten Semarang, sebagian besar tidak memberikan ASI eksklusif.

Banyak ibu yang tidak memberikan ASI eksklusif dikarenakan berbagai faktor. Salah satunya adalah pengetahuan ibu masih rendah. Hal ini bisa dilihat dari hasil isian kuesioner, dimana lebih banyak ibu memiliki pengetahuan yang rendah tentang ASI eksklusif sejumlah 29 orang $(38,2 \%)$. Menurut Notoatmojo (2012) Pengetahuan atau kognitif merupakan domain yang sangat penting dalam membentuk tindakan seseorang (overt behavior). Karena dari pengalaman dan penelitian ternyata perilaku yang didasarkan oleh pengetahuan akan lebih langgeng daripada perilaku yang tidak didasari oleh pengetahuan.

Banyak ibu di RW 05 Desa Karangjati Wilayah Kerja Puskesmas Bergas Kabupaten Semarang yang tidak memberikan ASI eksklusif juga bisa dikarenakan sebagian ibu di RW 05 Desa Karangjati ini dalam setiap harinya sibuk bekerja. Hal ini sebagaimana dari hasil isian kuesioner, dimana sebagian besar responden bekerja sejumlah 44 orang $(57,9 \%)$. Ibu-ibu yang bekerja atau kesibukan sosial lainnya tentu akan memiliki waktu yang terbatas bersama bayinya, sehingga kesempatan untuk menyusui bayinya juga berkurang. Hal ini membuat ibu beralih untuk memberikan susu formula sebagai ganti karena ibu tidak sempat menyusui bayinya. Apalagi pada saat ini banyak iklan di televisi yang menawarkan berbagai susu formula. Iklaniklan tersebut seringkali mempromosikan bahwa susu formula yang ditawarkannya sangat baik bagi pertumbuhan dan perkembangan bayi. Banyaknya iklan ini mengakibatkan para ibu menjadi terbujuk dan tertarik untuk memberikan susu formula kepada bayinya terutama pada ibu bekerja yang tidak sempat menyusui bayinya.

Selain itu, beberapa rumah sakit malah memberikan susu formula pada bayi yang baru lahir sebelum ibunya mampu memproduksi ASI. Hal ini menyebabkan bayi tidak terbiasa menghisap ASI dari puting susu ibunya dan akhirnya tidak mau lagi mengkonsumsi ASI atau sering disebut dengan "binggung puting". Menghisap susu dari botol sangat berbeda dengan menghisap puting susu ibu. Bayi baru belajar sejak awal dan ibu juga harus belajar menyusui karena keterampilan itu memang harus dipelajari oleh keduannya (Yuliarti, 2010). 


\section{KESIMPULAN}

1. Sebagian besar ibu yang memiliki bayi 6-12 bulan di RW 05 Desa Karangjati Wilayah Kerja Puskesmas Bergas Kabupaten Semarang berpendidikan menengah (SMA sederajat) sejumlah 35 orang $(46,1 \%)$.

2. Ibu yang memiliki bayi 6-12 bulan di RW 05 Desa Karangjati Wilayah Kerja Puskesmas Bergas Kabupaten Semarang lebih banyak didominasi oleh ibu yang bekerja sejumlah 44 orang $(57,9 \%)$.

3. Pengetahuan ibu tentang ASI eksklusif di RW 05 Desa Karangjati Wilayah Kerja Puskesmas Bergas Kabupaten Semarang lebih banyak dalam kategori kurang, sejumlah 29 orang $(38,2 \%)$.

4. Ibu yang memiliki bayi 6-12 bulan di RW 05 Desa Karangjati Wilayah Kerja Puskesmas Bergas Kabupaten Semarang, sebagian besar tidak memberikan ASI eksklusif sejumlah 52 orang $(68,4 \%)$.

5. Tidak ada hubungan secara bermakna antara pendidikan dengan pemberian ASI eksklusif pada ibu yang memiliki bayi usia 6-12 bulan di RW 05 Desa Karangjati Wilayah Kerja Puskesmas Bergas Kabupaten Semarang Berdasarkan dengan p-value 0,720 > $\alpha$ $(0,05)$.

6. Ada hubungan secara bermakna antara pekerjaan dengan pemberian ASI eksklusif pada ibu yang memiliki bayi usia 6-12 bulan di RW 05 Desa Karangjati Wilayah Kerja Puskesmas Bergas Kabupaten Semarang dengan pvalue $0,007<\alpha(0,05)$.

7. Ada hubungan secara bermakna antara pengetahuan dengan pemberian ASI eksklusif pada ibu yang memiliki bayi usia 6-12 bulan di RW 05 Desa Karangjati Wilayah Kerja Puskesmas Bergas Kabupaten Semarang dengan pvalue 0,020 .

\section{DAFTAR PUSTAKA}

Ambarwati \& Wulandari. 2009. Asuhan Kebidanan (Nifas). Cetakan ketiga, Jakarta : Mitra Cendikia

Alimul Hidayat. (2007). Metode Penelitian Kebidanan Dan Tehnik Analisis Data. Surabaya: Salemba.

Anoraga Panji. (2009). Psikologi Kerja. Jakarta: rineka Cipta.

Arikunto, Suharsimi. (2010). Prosedur Penelitian. Yogyakarta: Rineka Cipta.

Dinkes Kabupaten Semarang. (2013). Profil Kesehatan Angka Tahun 2013. Ungaran: Dinas Kabupaten Semarang.

Effendi, N. (2008). Dasar-Dasar Pendidikan Kesehatan

Masyarakat. Edisi 2. Jakarta: EGC.

Kristiyansari, Weni. (2009). ASI, Menyusui dan Sadari. Yogyakarta: Medika.

Maryunani, Anik. (2012). Inisiasi Menyusui Dini, ASI Eksklusif dan Manajemen Laktasi. Jakarta : TIM

Nursalam. (2009). Konsep Dan Penerapan Metodologi Penelitian Ilmu Keperawatan. Jakarta: Salemba Medika.

Notoatmodjo. (2005). Metode Penelitian Kesehatan. Jakarta : Rineka Cipta.

Notoatmodjo. (2012). Promosi Kesehatan dan Perilaku Kesehatan. Jakarta: Rineka Cipta.

Prastyono, Dwi Sunar. (2012). Buku Pintar ASI Eksklusif. Yogyakarta: Diva Press.

Pratiwi. (2008). Kendala Pemberian ASI Eksklusif. Jakarta : Ikatan Dokter Anak Indonesia.

Roesli, Utami. (2008). Inisiasi Menyusui Dini. Jakarta : Pustaka Bunda.

Roesli, Utami. (2005). ASI Eksklusif. Jakarta : Pustaka Pembangunan Swadaya Nusantara.

Saryono. 2011. Metodologi Penelitian Kesehatan. Yogyakarta : Nuha Medika. 


\section{JGK-vol.7, no.16 Oktober 2015}

Sugiyono. 2010. Metode Penelitian Yuliandari. (2009). Psikologi Ibu Dan Kualititatif dan $R \& D$. Bandung : $\quad$ Anak. Penerbit Andi. Yogyakarta. Alfabeta.

Sugiyono. 2010. Statistik Untuk Penelitian. Bandung : Alfabeta. 